Joanna RUDAWSKA, PhD

Faculty of Law and Social Sciences, Jan Kochanowski University in Kielce

e-mail: jrudawska@ujk.edu.pl

ORCID: 0000-0003-1484-8283

DOI: $10.15290 /$ oes.2020.01.99.09

\title{
IN SEARCH OF MEDIATORS IN THE RELATIONSHIP BETWEEN ENTREPRENEURIAL ORIENTATION AND PERFORMANCE: THE MEDIATING ROLE OF TECHNOLOGY PARK SUPPORT ${ }^{1}$
}

\begin{abstract}
Summary
Purpose - The aim of this paper is to determine the role of the technology park support in the relationship between entrepreneurial orientation (EO) and enterprise performance.

Research method - A multi-stage statistical analysis with elements of econometrics was utilised. The reliability of individual scales by Cronbach's alpha test was performed. Variables were treated as reflective and latent and exploratory and confirmatory factor analysis was performed. The relationship between the variables studied (analysis of Pearson correlation and Tau-B Kendall) was assessed. The Structural Equation Modelling (SEM) technique was used, including mediation analysis.

Results - Technology park support is not a significant mediator of the relationship between EO and performance.

Originality / value / implications / recommendations - The study results are a good starting point for further research to identify the variables which mediate the EO-performance relationship. They are also an inspiration to examine why companies in technology parks do not use the offer of support from these centres.
\end{abstract}

Keywords: entrepreneurial orientation, performance, technology park, mediation

JEL Classification: M20

\section{Introduction}

In times of a permanently changing environment, the competitive advantage of a company is based on the ability of a constant development of its organisational skills that facilitate an efficient response to the dynamically changing circumstances [Pukkinen, 2018, pp. 79-104]. In a turbulent environment, companies are forced to act to maintain their market position. Therefore, it is necessary to implement

${ }_{1}^{1}$ Article received on 28 August 2019, accepted on 2 December 2019. 
innovation, predict future needs, changes and problems and respond to them at the right time and in the right way, frequently reducing the risk of failure. Entrepreneurial orientation (EO), as one of the strategic orientations plays an important role in the exploration of market opportunities, development of new ideas and effective use of resources [Wójcik-Karpacz, 2019]. There are many examples where the subject literature has provided arguments that a high entrepreneurial orientation is a guarantee of higher efficiency for an organisation, which is a successful tool to achieve and maintain the competitive advantage [Dyduch, 2008; Bratnicki, Gabryś, 2011; Rauch et al., 2009; Gupta, Gupta, 2015; Wales, 2016]. However, there is an absence of studies on the relationship between the entrepreneurial orientation and the performance of companies located in technology parks, comprehensive innovation centres created with the goal to provide support for technological and innovative companies, who provide advisory, training and business care at each stage of a company development. According to the assumption that technology parks should incubate technological enterprises that are more innovative, proactive and open to taking risks, it is extremely interesting whether support from such entities has an impact on the EO-performance relationship [Wójcik-Karpacz, Rudawska, 2016, pp. 248-264]. Therefore, the purpose of this study is to determine the role of a technology park support in the relationship between the EO and performance of an enterprise operating within a technology park, according to quantitative results of empirical studies. This article includes a review of subject literature, the characteristics of studied variables and the adopted research procedure. The final part presents the study results, its limitations and a proposal for further research.

\section{Review of subject literature}

The EO construct originates from the literature on strategic management [Mintzberg, 1973 pp. 44-53; Miller 1983, pp. 770-791; Dyduch, Bratnicki, 2018, pp. 7-26] and refers to the process of taking strategic decisions in an enterprise. According to Miller's conceptualisation, EO is a continuum ranging from conservative organisations at one end and entrepreneurial ones at the other. He defined entrepreneurial organisations as those characterised with innovativeness, proactiveness and risk-taking. At the other end of the continuum, he placed conservative organisations. This approach has been confirmed in the literature by Covin and Slevin [1989, pp. 75-87]. EO as a multi-dimensional construct is usually considered in three dimensions of innovativeness, proactiveness and risk-taking [Rauch et al., 2009, pp. 761-787; Covin, Wales, 2012, pp. 677-702]. The first of the dimensions is proactiveness, which may be operationalised on the level of an enterprise by asking managers about the company's tendency to be the first in the market to introduce a new technology, product or service. The innovativeness of an organisation is its willingness to be innovative and its capacity to introduce and implement new products, services or ideas [Rudawska, 2017, pp. 9-21]. Willingness to innovate was studied by asking managers about the number of new products / service lines 
introduced in the company, as well as the level of radical changes thus proposed. The third component of the construct, i.e. risk-taking is defined as an acceptable level to which managers are willing to make risky commitments which may possibly lead to a failure. In this case, company risk-taking is measured by its willingness to join risky projects, and also managerial preferences for bold rather than cautious actions [Wiklund, Shepherd, 2003, pp. 1307-1314].

In this study, Covin and Slevin's EO definition and scale were adopted [1989, pp. 75-87]. Also, referring to Miller's original conceptualisation of EO proposed in 1989, indicating that it includes concurrent implementation of innovative, proactive and risky behaviour of an organisation, a one-dimension approach to the study was adopted, where three elementary components positively co-vary to express the orientation of the organisation. Since EO is a latent construct, as it is a phenomenon within the field of theoretical interest, then it cannot be observed directly and must be estimated with the use of visible and observable variables [Karpacz, 2016, pp. 9-15; McKenzie et al., 2005, pp. 710-730; Diamantopoulos et al., 2008, pp. 1203-121]. Therefore, it was assumed that EO as a latent construct is shaped as a combination of its indicators.

In the subject literature reviewed, it was discussed that the relationship between $\mathrm{EO}$ and a firm's performance is much more complex and there are other aspects, internal and external, which have an impact on firms, which should be studied and understood better. According to the researchers, this relationship is a type of a „transmission belt” between EO and firm's performance [Lumpkin, Dess, 1996, pp. 135-172]. These findings open the pathway to search for variables which might influence this relationship. Such variables may be divided into moderators and mediators. Moderators describe the limitations of the studied phenomenon, while mediators explain why such phenomenon occurs. Mediation is an analytical technique which allows to study significant deviations in the size and direction of the EO-performance relationship [Bedyńska et al., 2012, pp. 18-22].

The relationship between entrepreneurial orientation and the firm's performance has been the subject of research of multiple scholars [Rauch et al., 2009, pp. 761-787] who proved that such a relationship exists. However, the subject literature also describes empirical studies that indicate a lack of a clear-cut explanation of the EO-performance relationship. Therefore, it may be assumed that such a relationship exists however it does not have a direct character, i.e. indirect or partial mediation. It may be also hypothesised that a lack of a direct influence of entrepreneurial orientation on the firm's performance does not mean a total lack of such impact, but only means that there is no direct influence [Zbierowski, 2012, p. 34]. Therefore, the introduction of a new mediating element to the study may explain the interdependencies between constructs.

Studies on the variables mediating the EO-performance relationship are less popular than studies of its moderators [Wales et al., 2013, pp. 93-121, Harms, 2013, pp. 357-432]. Out of 158 articles analysed by Wales et al., in 64 cases the researchers tried to verify the impact of moderating variables (such as environment, organisation learning, human resources, strategy, leadership, networking, culture, etc.) on 
the EO-performance relationship. Studies on mediators are less popular (16 out of 158 articles mentioned above). In Poland, studies in this area were conducted by Pichlak [2012, pp. 219-233] in the field of organisational innovation. This opens the opportunities for further exploration of the concept as a useful technique to analyse the EO-performance relationship. Studies conducted abroad allowed to propose a list of so far identified mediators for the EO-performance relationship, i.e. organisational learning, innovative strategy of an organisation, innovation, certification, commitment, management by objectives, corporate entrepreneurship activities, human capital, social capital, customer capital, supplier relations, brand strength, information acquisition and utilisation, or corporate entrepreneurship support [Wójcik-Karpacz, 2017, pp. 85-97]. Therefore, an attempt was made to complete the list of mediating variables or exclude from it another factor that is the technology park support.

Companies located in technology parks often use the support offered at preferential conditions by these institutions from business environment [Rudawska, 2016]. Such activity might have an influence on the EO-performance relationship. Technology park support has been treated as a mediator, similarly to managerial support as an activity for corporate entrepreneurship in the research conducted by Fis and Cetindamar [2009, pp. 1819-1829] on corporate entrepreneurship, who confirmed the full mediation of the EO-performance relationship. Fis and Cetindamar indicated results such as growth, profitability and non-financial performance, and they used the Covin and Slevin scale for the EO study.

Therefore, one main hypothesis and two detailed hypotheses were formulated:

H1. Technology park support mediates the relationship between the entrepreneurial orientation and the firm's performance.

H1a. Technology park support mediates the relationship between the entrepreneurial orientation and the firm's financial performance.

H1b. Technology park support mediates the relationship between the entrepreneurial orientation and the firm's non-financial performance.

The conceptual model, studied constructs and expected dependencies are presented in chart 1.

\section{CHART 1}

\section{Research model}

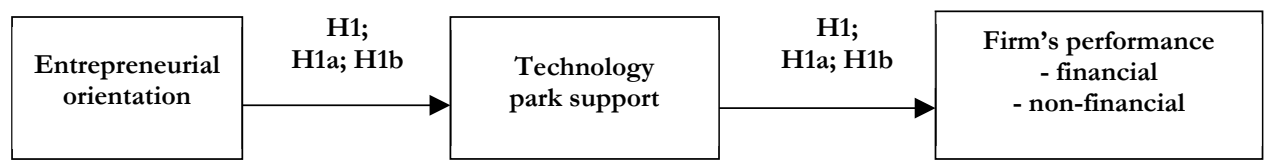

Source: own elaboration.

Technology park support has been treated as a mediator for the EO-performance relationship. 


\section{Research method}

A quantitative empirical study was conducted from 1 April to 15 June 2017 by the author. and paid for from her own funds. The study group included tenants of technology parks in Poland, i.e. decision makers in companies, who answered questions included in the survey questionnaire. The study was conducted with the use of CAWI (Computer Assisted Web Interviews).

For the purpose of the study, a database of technology parks was used, which included 1564 firms (as of 31.03.2017), kept by the Business and Innovation Centres Association in Poland (Stowaryyszenie Organizatorón Ośrodkón Innowacji i Przedsięiorcrosici w Polsce - SOOIP). In this study, they constitute the general population. It is the only database in Poland which is regularly updated by technology parks. Finally, 117 firms took part in the study, which constituted $7.5 \%$ of the general population.

In the sample group, $50 \%$ of firms were companies operating on the market from 1 year (or shorter) to 3 years. Firms active in the market from 4 to 6 years constituted $20 \%$ of the sample group, and companies operating from 7 to 9 years constituted only $12 \%$. Mature companies, of 10 years or more of experience constituted $18 \%$ of the sample group. The majority, i.e. $57 \%$ of companies included in the study were micro companies employing from 1 to 9 employees. The next group was small companies ( $22 \%$ of the sample group). Medium and large enterprises together amounted to $10 \%$ of the sample group. Taking into consideration the main object of operation as per the statistical number (REGON) as defined by the Polish Classification of Business Activities (PKD), the majority in the sample group were service companies (69\%), including those related to ICT and involved in professional, scientific and technical activities. Manufacturing companies constituted $20 \%$ and trading companies $-10 \%$ of the sample group.

To measure the variables, scales described in the subject literature and the author's own research tools were applied. In all cases, the 7-point Likert scale was employed.

Independent variable - To measure EO, the Covin and Slevin's scale [1989] was adopted, which assumed the three-dimensional approach to the construct, i.e. innovativeness, proactiveness and risk-taking. Cronbach's Alpha amounted to 0.877 which corresponds to a high reliability of the scale. However, the exploratory factor analysis showed that it is justified to identify only two and not three of the initially assumed dimensions; and these two dimensions explain almost $70 \%$ of variances. Therefore, two dimensions of EO were adopted, i.e. innovativeness and proactiveness (treated jointly) and the dimension of risk-taking. The situation of grouping a different number of dimensions is known in the subject literature. Reconceptualisation of the entrepreneurial orientation construct in such an arrangement was proposed by Anderson et al. [2015, pp. 1582-1583]. Researchers proposed two elements: entrepreneurial behaviour (innovativeness and proactiveness) and the managerial approach to risk.

Dependant variable - With respect to the study of the company's performance, it was decided to apply the division into financial and non-financial results 
[Keh et al., 2007], according to the subjective measurement of the owners feelings in comparison to the competition covering the period of 3 years backwards, or a respective period if the company existed shorter than that. Cronbach's alpha for financial performance amounted to 0.936 , and non-financial -0.898 , which is the evidence of similar understanding of the questions. Factor analysis was conducted for financial and non-financial results treated jointly, which confirmed that all variables create one dimension which explain the significant value of variances (73.043\%).

Mediating variable - To measure the support of technology park, the author's own tool was used. It was in the form of a questionnaire checking access to infrastructure, training services, advisory services, $\mathrm{R}+\mathrm{D}$ services, promotion, establishing contacts and internationalisation. Cronbach's alpha for this scale amounted to 0.847 which confirms the high reliability of the tool. Technology park support was treated as a latent variable, and according to the results of the factor analysis, its differentiators include 6 , and not 7 issues (excluding infrastructural support). The model was estimated with a high goodness-of-fit criteria which respectively amounted to 0.056 for RMSEA 0.940 for CFI and 0.931 for TLI. The level of explanation of the dependant variable is high and amounts to 39.8\% and is statistically significant.

Control variables - Control variables were introduced to the created model, including the age of the company, its size and number of owners (women and men in total), and the number of women who are owners or co-owners. Control variables, especially a company's age and size are often used in EO studies [e.g. WójcikKarpacz et al., 2019; Dyduch, 2008]. The variable number of owners and women owners was included due to the available subject studies concerning management in companies located in technology parks including the division into men and women [Mażewska, 2014].

To verify the research hypotheses, the authors used the multi-stage statistical analysis with elements of econometrics. At first, the data had to be studied by way of a detailed description and analysis of individual elements of the study tool. The principal theoretical constructs (entrepreneurial orientation, financial results, nonfinancial results and the technology park support) were initially tested with respect to their reliability (Cronbach's alpha test), and next an exploratory factor analysis was conducted. For all scales, in the next step, confirmatory factor analysis was conducted. For the purpose of those analyses, SPSS and Mplus statistical packages were applied; simple analyses were performed in Excel (pivot tables, analyses of means and deviations). In this part, also mean levels and standard deviations for individual issues were presented, with the use of pivotal tables available in Excel. The purpose of the next research step was to evaluate the relationship between the studies variables. For that purpose, the analyses of Pearson's correlation and Kendall's Tau-B coefficient were used. Following this, the technique of structural equation modelling was used including the mediation analysis. It allows for testing research hypotheses of high possible complexity of relations between variables in studies of relations, including unobservable ones [Ejdys, 2014]. 


\section{Study results}

The principal statistical data, including means, medians and standard deviations for individual dimensions were prepared to provide better presentation of the dependencies between the studied latent variables. Descriptive statistical data are presented in table 1.

TABLE 1

\section{Descriptive statistical data}

\begin{tabular}{|c|c|c|c|c|c|}
\hline \multirow{2}{*}{ Construct } & \multirow{2}{*}{ Dimension } & \multicolumn{2}{|c|}{$\mathbf{N}$} & \multirow{2}{*}{ Mean } & \multirow{2}{*}{$\begin{array}{l}\text { Standard } \\
\text { deviation }\end{array}$} \\
\hline & & Correct & Missing & & \\
\hline \multirow{3}{*}{$\begin{array}{l}\text { Entrepreneurial } \\
\text { orientation }\end{array}$} & Innovativeness & 117 & 0 & 4.00 & 2.03 \\
\hline & Proactiveness & 117 & 0 & 4.30 & 1.86 \\
\hline & Risk-taking & 117 & 0 & 4.48 & 1.76 \\
\hline \multirow{7}{*}{$\begin{array}{l}\text { Technology } \\
\text { park support }\end{array}$} & Access to infrastructure & 117 & 0 & 5.38 & 1.95 \\
\hline & Training services & 117 & 0 & 3.01 & 1.91 \\
\hline & Advisory services & 117 & 0 & 2.57 & 1.79 \\
\hline & R\&D services & 117 & 0 & 2.10 & 1.65 \\
\hline & $\begin{array}{l}\text { Company's promotion } \\
\text { by the technology park }\end{array}$ & 117 & 0 & 3.50 & 2.03 \\
\hline & $\begin{array}{l}\text { Establishing business } \\
\text { contacts }\end{array}$ & 117 & 0 & 3.49 & 1.99 \\
\hline & $\begin{array}{l}\text { Support for internatio- } \\
\text { nalisation }\end{array}$ & 117 & 0 & 2.11 & 1.61 \\
\hline \multirow{2}{*}{$\begin{array}{l}\text { Company's } \\
\text { performance }\end{array}$} & $\begin{array}{l}\text { Financial total: profitability, } \\
\text { sales increase, market share, } \\
\text { general company's } \\
\text { performance }\end{array}$ & 117 & 0 & 3.94 & 1.70 \\
\hline & $\begin{array}{l}\text { Non-financial total: adopted } \\
\text { goals, employment guarantee } \\
\text { for employees, satisfaction } \\
\text { with achieved results. }\end{array}$ & 117 & 0 & 4.64 & 1.44 \\
\hline
\end{tabular}

Source: own elaboration.

The analysis of the descriptive statistical data above shows that the studied companies can be characterized with a higher than average levels in all three EO dimensions. The level of risk-taking is the highest and amounts to 4.8 , and the mean level of innovativeness and proactiveness amounted to 4.00 and 4.30 respectively. The standard deviations in all dimensions are quite high, although only in the case of innovativeness it is higher than 2 and amounts to 2.03. This means that in the studied group there are both entrepreneurial companies as well as those which are conservative.

$\mathrm{EO}$ is understood in the strategic dimension and allows to observe the strategic position of a company, shifting along the continuum from totally conservative to fully entrepreneurial. Accordingly, it may be stated that companies who are eager to 
get involved in activities which require risk-taking, innovativeness and proactiveness represent entrepreneurial behaviour, while those who show a low level of such behaviour represent a conservative orientation.

Analysis of data concerning technological park support indicates that companies operating in such centres are willing to enjoy access to the infrastructure (mean 5.38), while other services are less popular. Half of the companies located in technology parks do not use at all their support with respect to internationalisation or R\&D services. The standard deviations of answers represent moderate values and only in one case (company's promotion by the technology park) they are higher than 2 , and amount to 2.03. Therefore, companies in the sample group are not homogenous in that respect.

Answers to questions concerning financial and non-financial results have moderate means of 3.94 and 4.64. The assessment of non-financial results is higher than the assessment of financial results. In both cases, standard deviation does not exceed 2.

The following table 2 presents correlations between the dimensions of studied constructs.

TABLE 2

Pearson's linear correlation coefficient among the studied variables

\begin{tabular}{|c|c|c|c|c|c|c|c|}
\hline & & $\begin{array}{l}\text { Technology } \\
\text { park } \\
\text { support }\end{array}$ & $\begin{array}{c}\text { Financial } \\
\text { result }\end{array}$ & $\begin{array}{c}\text { Non- } \\
\text { financial } \\
\text { result }\end{array}$ & $\begin{array}{c}\text { Financial } \\
\text { and non- } \\
\text { financial } \\
\text { result }\end{array}$ & $\begin{array}{c}\text { Innova- } \\
\text { tiveness and } \\
\text { proactiveness }\end{array}$ & Risk-taking \\
\hline \multirow{2}{*}{$\begin{array}{l}\text { Technology } \\
\text { park support }\end{array}$} & Pearson & 1 & $0.401^{* *}$ & $0.329^{* *}$ & $0.396^{* *}$ & $0.376^{* *}$ & $0.423^{* *}$ \\
\hline & $\mathrm{p}$ & & 0.000 & 0.000 & 0.000 & 0.000 & 0.000 \\
\hline \multirow{2}{*}{ Financial result } & Pearson & & 1 & $0.734^{* *}$ & $0.948^{* *}$ & $0.468^{* *}$ & $0.375^{* *}$ \\
\hline & $\mathrm{p}$ & & & 0.000 & 0.000 & 0.000 & 0.000 \\
\hline \multirow{2}{*}{$\begin{array}{l}\text { Non-financial } \\
\text { result }\end{array}$} & Pearson & & & 1 & $0.913^{* *}$ & $0.422^{* *}$ & $0.321^{* *}$ \\
\hline & $\mathrm{p}$ & & & & 0.000 & 0.000 & 0.000 \\
\hline \multirow{2}{*}{$\begin{array}{l}\text { Financial and } \\
\text { non-financial } \\
\text { result }\end{array}$} & Pearson & & & & 1 & $0.481^{* *}$ & $0.377^{* *}$ \\
\hline & $\mathrm{p}$ & & & & & 0.000 & 0.000 \\
\hline \multirow{2}{*}{$\begin{array}{l}\text { Innovativeness } \\
\text { and proacti- } \\
\text { veness }\end{array}$} & Pearson & & & & & 1 & $0.603^{* *}$ \\
\hline & $\mathrm{p}$ & & & & & & 0.000 \\
\hline \multirow{2}{*}{ Risk-taking } & Pearson & & & & & & 1 \\
\hline & $\mathrm{p}$ & & & & & & \\
\hline
\end{tabular}

Source: own elaboration.

Pearson's linear correlation coefficients presented in Table 2 show mutual correlations among all variables. It is the lowest in the case of the relationship 
between the risk-taking and non-financial results and amounts to 0.321 , while for the relationship between financial results and non-financial results it amounts to 0.734 .

$\mathrm{EO}$ as an independent variable measured in two dimensions (innovativeness and proactiveness and risk-taking) is significantly related both with financial and nonfinancial results, as well as the technological park support, and the correlation coefficients in this respect are significant (above 0.3). It should be stressed that they are all statistically significant on the level of $\mathrm{p}<0.01$. Park support is also significantly related with financial results, non-financial results and overall company's performance.

To assess the relationship between EO dimensions and the firm's performance, including the mediating role of park support for firms' operation, the structural equation modelling was applied with mediation analysis in Mplus software for Mac. Technology park support for a company's operation was treated as a latent variable, taking into consideration 6 , instead of 7 studied issues. The model was assessed with a high goodness-of-fit criteria, which amounted to 0.056 for RMSEA, 0.940 for CFI and 0.931 for TLI. The level of explanation of the dependant variable is high and amounts to $39.8 \%$ and is statistically significant. The model is presented in chart 2 .

The analysis of the estimated model shows that out of two dimensions of EO, only the dimension of innovativeness and proactiveness is the one which significantly influences the company's performance (i.e. financial results and non-financial results treated jointly). On the other hand, risk-taking influences the usage of support from the technology park, which in turn is related to the company's performance, though the significance of this dependence is moderate, since it was estimated at the level of $\mathrm{p}<0.1$. Among the control variables, only the company's size is a significant determinant for company's performance.

Mediation analysis, conducted as part of the model estimation shows clearly that technological park support is not a significant mediator of the relationship between the dimensions of EO and firm's performance. However, as such it is significant in influencing the company's performance, though as it was mentioned, this significance has been estimated on a relatively high level $(\mathrm{p}=0.088)$ and this relationship should be treated with caution. Therefore, it is not possible to confirm that hypothesis H1 is true. Technological park support is a significant mediator of the principal dependence. However, by itself it is determined by risk-taking and at the same time it has a moderate influence on the company's performance. 


\section{CHART 2}

Model of dependencies among dimensions of entrepreneurial orientation and financial and non-financial results in the context of the company's size, age, number of owners and number of women owners - mediating role of the technology park support

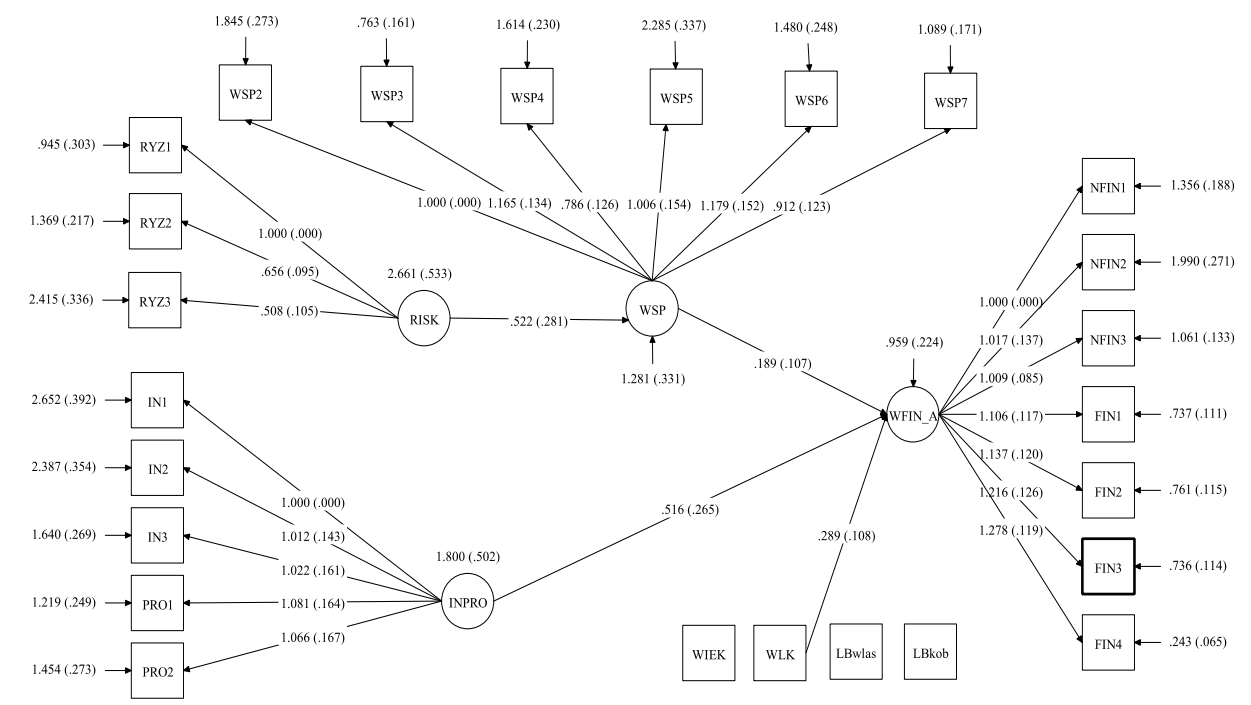

Key:

IN1-IN3 - questions concerning company's innovativeness

PRO1-PRO2 - questions concerning company's proactiveness

RYZ1-RYZ2 - questions concerning risk-taking by a company

INPRO - dimension of company's innovativeness and proactiveness (latent variable)

RISK - dimension of company's risk-taking (latent variable)

WSP2-WSP7 - questions concerning technology park support for company's operation

WSP - technology park support for company's operation (latent variable)

WFIN_A - dimension of company's financial and non-financial results

NFIN1-NFIN3 - questions concerning company's non-financial results

FIN1-FIN4 - questions concerning company's financial results

Wiek - duration of the company

Wlk - company's size measured with number of employees

LBkob - number of women (owners)

LBWlas - number of company owners

Source: own elaboration according to analyses conducted with Mplus software for Mac.

Finally, to verify the proposed research hypotheses, one more estimation of the model parameters was conducted, where financial results and non-financial results were treated separately. The findings are presented in chart 3. 


\section{CHART 3}

Model of dependencies among dimensions of entrepreneurial orientation and financial and non-financial results treated separately in the context of the company's size, age, number of owners and number of women owners mediating role of the technology park support

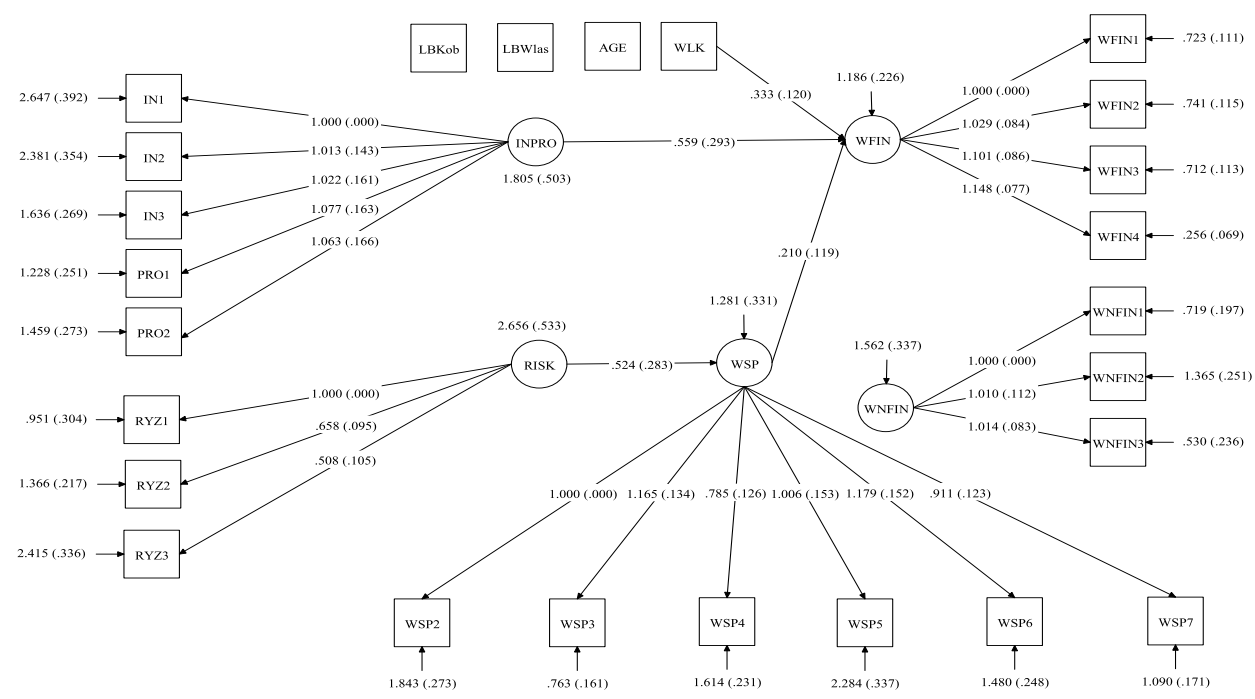

Key:

IN1-IN3 - questions concerning company's innovativeness

PRO1-PRO2 - questions concerning company's proactiveness

RYZ1-RYZ2 - questions concerning risk-taking by a company

INPRO - dimension of company's innovativeness and proactiveness (latent variable)

RISK - dimension of company's risk-taking (latent variable)

WSP2-WSP7 - questions concerning technology park support for company's operation

WSP - technology park support (latent variable)

WFIN - dimension of company's financial results

WNFIN - dimension of company's non-financial results

NFIN1-NFIN3 - questions concerning company's non-financial results

FIN1-FIN4 - questions concerning company's financial results

Wiek - duration of the company

Wlk - company's size measured with number of employees

LBkob - number of women (owners)

LBWlas - number of company owners

Source: own elaboration according to analyses conducted with Mplus software for Mac.

The model presented in chart 3 was estimated at a satisfactory level (RMSEA $=$ $0.054, \mathrm{CFI}=0.949$, TLI $=0.940)$ and explains respectively $39.5 \%$ of variability of financial results and $30.5 \%$ of variability of non-financial results. The chart presents only the statistically significant relationships. Interestingly, the non-financial results 
are not significantly determined by either of the studied variables. However, similarly to previous models, the financial results are influenced by innovativeness and proactiveness, the company's size and, to a smaller degree, the technology park support (significance $\mathrm{p}=0.077$ ). Park support does not significantly mediate the relationship between the dimensions of the entrepreneurial orientation and company's financial and non-financial results, which is an argument to reject the hypotheses H1a and $\mathrm{H} 1 \mathrm{~b}$ which propose the existence of such relationship. According to the presented arguments, there is no evidence supporting the hypothesis of the mediating role of the technology park support, however the fact of using the park support is a variable allowing to understand better and explain the level of company's financial results.

After making the models' estimation, their comparative analysis was conducted.

TABLE 3

\section{Comparative analysis of estimated models of relationships between entrepreneurial orientation, technology park support and company's performance, including financial and non-financial results}

\begin{tabular}{|c|c|c|}
\hline Model number & Model 1 & Model 2 \\
\hline Model subject & $\begin{array}{l}\text { Model of relationship between the } \\
\text { dimensions of entrepreneurial } \\
\text { orientation and company's performance } \\
\text { (financial and non-financial results } \\
\text { jointly) in the context of the company's } \\
\text { size, duration, number of owners } \\
\text { and women (owners) - mediating role } \\
\text { of the technology park support }\end{array}$ & $\begin{array}{l}\text { Model of relationship between the } \\
\text { dimensions of entrepreneurial } \\
\text { orientation and company's financial } \\
\text { and non-financial results separately } \\
\text { in the context of the company's size, } \\
\text { duration, number of owners } \\
\text { and women (owners) - mediating } \\
\text { role of the technology park suppor }\end{array}$ \\
\hline RMSEA & 0.057 & 0.054 \\
\hline CFI & 0.940 & 0.949 \\
\hline TLI & 0.931 & 0.940 \\
\hline $\mathrm{r}^{2}$ for financial results & - & $0.395(\mathrm{p}=0.000)$ \\
\hline $\mathrm{r}^{2}$ for non-financial results & - & $0.302(\mathrm{p}=0.002)$ \\
\hline \multirow[t]{2}{*}{$\begin{array}{l}\mathrm{r}^{2} \text { for company's } \\
\text { performance (financial and } \\
\text { non-financial results jointly) }\end{array}$} & $0.398(\mathrm{p}=0.000)$ & - \\
\hline & Parameter (estimation error. p value) & Parameter (estimation error. p value) \\
\hline \multicolumn{3}{|c|}{ Dimensions of entrepreneurial orientation - impact on financial results } \\
\hline $\begin{array}{l}\text { Innovativeness and } \\
\text { proactiveness }\end{array}$ & 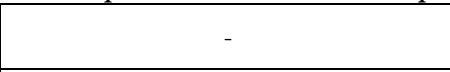 & $0.559(0.293 ; 0.049)$ \\
\hline Risk-taking & - & $-0.064(0.253 ; 0.799)$ \\
\hline \multicolumn{3}{|c|}{ Dimensions of entrepreneurial orientation - impact on non-financial results } \\
\hline $\begin{array}{l}\text { Innovativeness and } \\
\text { proactiveness }\end{array}$ & - & $0.600(0.346 ; 0.083)$ \\
\hline Risk-taking & - & $-0.132(0.300 ; 0.660)$ \\
\hline \multicolumn{3}{|c|}{ Dimensions of entrepreneurial orientation - impact on financial and non-financial results } \\
\hline $\begin{array}{l}\text { Innovativeness and } \\
\text { proactiveness }\end{array}$ & $0.516(0.265 ; 0.047)$ & - \\
\hline Risk-taking & \begin{tabular}{|c|}
$-0.063(0.225 ; 0.780)$ \\
\end{tabular} & - \\
\hline \multicolumn{3}{|c|}{$\begin{array}{l}\text { Dimension of technology park support for company's operation - impact in company's performance } \\
\text { (financial and non-financial results jointly) }\end{array}$} \\
\hline Technology park support & \begin{tabular}{|c|}
$0.189(0.107 ; 0.075)$ \\
\end{tabular} & \\
\hline \multicolumn{3}{|c|}{ Technology park support - impact on financial results } \\
\hline Technology park support & 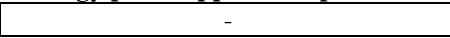 & $\begin{array}{r}0.210(0.119 ; 0.077) \\
\end{array}$ \\
\hline \multicolumn{3}{|c|}{ Technology park support - impact on non-financial results } \\
\hline Technology park support & 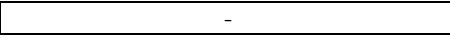 & $\begin{array}{r}0.213(0.144 ; 0.139) \\
\end{array}$ \\
\hline
\end{tabular}




\begin{tabular}{|c|c|c|}
\hline Model number & Model 1 & Model 2 \\
\hline \multicolumn{3}{|c|}{ Control variables - impact on company's performance (financial and non-financial results jointly) } \\
\hline Company’s size & $0.289(0.108 ; 0.007)$ & - \\
\hline Company's duration & $-0.032(0.019 ; 0.088)$ & - \\
\hline Number of owners & $-0.085(0.089 ; 0.338)$ & - \\
\hline Number of women (owners) & $0.156(0.211 ; 0.459)$ & - \\
\hline \multicolumn{3}{|c|}{ Control variables - impact on financial results } \\
\hline Company’s size & -1 & $0.333(0.120 ; 0.005)$ \\
\hline Company's duration & - & $-0.035(0.021 ; 0.095)$ \\
\hline Number of owners & - & $-0.110(0.099 ; 0.266)$ \\
\hline Number of women (owners) & - & $0.159(0.235 ; 0.499)$ \\
\hline \multicolumn{3}{|c|}{ Control variables - impact on non-financial results } \\
\hline Company's size & -4 & $0.206(0.140 ; 0.141)$ \\
\hline Company's duration & - & $-0.036(0.025 ; 0.149)$ \\
\hline Number of owners & - & $0.031(0.117 ; 0.792)$ \\
\hline Number of women (owners) & - & $0.259(0.279 ; 0.353)$ \\
\hline \multicolumn{3}{|c|}{$\begin{array}{l}\text { Technology park support as the mediator of the relationship between the dimension of entrepreneuria } \\
\text { orientation and company's performance (financial and non-financial results jointly) }\end{array}$} \\
\hline $\begin{array}{l}\text { From innovativeness and } \\
\text { proactiveness dimension }\end{array}$ & $-0.026(0.065 ; 0.687)$ & - \\
\hline From risk-taking dimension & $0.099(0.082 ; 0.270)$ & - \\
\hline \multicolumn{3}{|c|}{$\begin{array}{c}\text { Technology park support as the mediator of the relationship between the dimension of entrepreneurial } \\
\text { orientation and company's financial results }\end{array}$} \\
\hline $\begin{array}{l}\text { From innovativeness and } \\
\text { proactiveness dimension }\end{array}$ & - & $-0.029(0.072 ; 0.687)$ \\
\hline From risk-taking dimension & - & $0.110(0.091 ; 0.225)$ \\
\hline \multicolumn{3}{|c|}{$\begin{array}{c}\text { Technology park support as the mediator of the relationship between the dimension of entrepreneurial } \\
\text { orientation and company's non-financial results }\end{array}$} \\
\hline $\begin{array}{l}\text { From innovativeness and } \\
\text { proactiveness dimension }\end{array}$ & - & $-0.030(0.075 ; 0.694)$ \\
\hline From risk-taking dimension & - & $0.112(0.104 ; 0.282)$ \\
\hline
\end{tabular}

Source: own elaboration according to conducted statistical analyses

Both models of structural equations presented were estimated on a high level of goodness of fit, with RMSEA respectively amounting to 0.057 and 0.054 . CFI and TLI indicators, which for the above models amounted to 0.940 and 0.949 , are also measures of a theoretical model fitting to empirical data. Determination coefficient $\left(\mathrm{r}^{2}\right)$ for the dependent variable, i.e. company's performance (financial and nonfinancial jointly) was high and amounted to 39.8\% and was statistically significant. For financial results $\mathrm{r}^{2}$ amounted to $39.5 \%$, and $30.2 \%$ for non-financial results. In both cases it was statistically significant.

\section{Conclusions}

The extensive model presented in the estimation shown in Chart 3, focused on the study of the impact of EO dimensions on the company's performance including the control variables and the mediating role of the technology park support for the company's operation, is well fitted. After the introduction of the variable of technology park support, the determination coefficient of the company's performance amounted to $39.8 \%$. A significant role in determining the company's results belongs to innovativeness and proactiveness, company's size and- to a smaller degree - tech- 
nology park support. The fact of using park support is determined by risk-taking. However, according to the analyses, technology park support is not a significant mediator of the relationship between the dimensions of EO and a company's performance. Furthermore, after subjecting the H1 hypothesis to a deeper testing, a model where financial results and non-financial results are treated separately was estimated. In that model, non-financial results are not significantly determined by any of the independent variables. However, financial results are determined by innovativeness and proactiveness, technology park support and company's size. The park support by itself as a determining factor for financial results should be treated with a certain caution, since this impact is significant with the significance level of less than 0.1. In this model, the mediation analysis has not led to the conclusion that park's support is a significant mediating factor for the relationship between dimensions of EO and financial and non-financial results treated jointly. As a result, it was determined that hypothesis $\mathrm{H} 1$, as well as the detailed hypotheses $\mathrm{H} 1 \mathrm{a}$ and $\mathrm{H} 1 \mathrm{~b}$ were not true. Therefore, the results reject the developed research model. Due to the size of the sample group, the results should not be generalised for all populations. The findings constitute a useful contribution to further research to identify variables mediating the EO-performance relationship, and they can also an inspiration to study why companies in technology parks do not use the support offered by those centres.

\section{References}

Anderson B.S, Kreisere P.M, Kuratko D.F, Hornsby J.S., Eshima Y., 2015, Reconceptualizing entrepreneurial orientation, "Strategic Management Journal", vol. 36, iss. 10, pp. 1582-1583, DOI: 10.1002/smj.2298.

Bedyńska S., Brzezicka A., Cypryańska M., 2012, Od teorii do analiøy statystycznej. Jak badać zjawiska psychologiczne?, [w:] Statystyczny drogowskaz. Wprowadzenie do wnioskowania statystycznego, Bedyńska S., Cypryańska M. (red.), Wyższa Szkoła Psychologii Społecznej, Warszawa.

Bratnicki M., Gabryś B.J., 2011, Orientacja præeedsiębiorcza a sukces organizacji, „Prace i Materiały Wydziału Zarządzania Uniwersytetu Gdańskiego", nr 4/2, s. 63-72.

Covin J. G., Wales W. J., 2012, The Measurement of Entrepreneurial Orientation, "Entrepreneurship. Theory \& Practice", vol. 36(4), pp. 677-702, DOI: 10.1111/j.15406520.2010.00432.x.

Covin J.G., Slevin D.P., 1989, Strategic management of small firms in hostile and begin environments, "Strategic Management Journal", vol. 10(11), pp. 75-87, DOI: 10. 1002/smj.4250100107.

Diamantopoulos A., Riefler P., Roth K.P., 2008, Advancing formative measurement models, "Journal of Business Research", vol. 61(12), pp. 1203-1218, DOI: 10.1016/ j.jbusres.2008.01.009.

Dyduch W., 2008, Pomiar przedsięiorczości organizacyjnej jako przesłanka podwyższania efektywności, „Organizacja i Zarzadzanie”, nr 4, s. 37-53. 
Dyduch W., Bratnicki M., 2018, Strategizing corporate entrepreneurship for value creation and value capture, "Journal of Contemporary Management", vol. 17, iss. 1, pp. 7-26, DOI: $10.4467 / 24498939 I J C M .18 .001 .8380$.

Ejdys J., 2014, Strategic orientation of small and medium size enterprises, „Economics and Management”, vol. 19, iss. 4, pp. 346-358, DOI: 10.5755/j01.em.19.4.8098.

Fis A.M., Cetindamar D., 2009, Unlocking the Relationship between Corporate Entrepreneurship and Performance, "PICMET 2009 Proceedings", Portland, Oregon USA, pp. 1819-1830.

Gupta V., Gupta A., 2015, The Concept of Entrepreneurial Orientation, "Foundations and Trends in Entrepreneurship", vol. 11, iss. 2, pp. 55-137, DOI: 10.1561/0300000054.

Harms R., 2013, From entrepreneurial orientation to performance: Inside the black box of corporate entrepreneurship, “M@n@gemen”, vol.16, iss.4,pp.357-432.

Karpacz J., 2016, Implikacje konceptualizacii dla modelowania konstruktu $i$ wskaźnikón orientacii przedsiebiorczej: ustalenia literaturowe „Management Forum”, nr 4(4), s. 9-15, DOI: 10.15611/mf.2016.4.02.

Keh H.T., Tuyet Mai Nguyen T., PingNg H., 2007, The effects of entrepreneurial orientation and marketing information on the performance of SMEs, "Journal of Business Venturing”, vol. 22, iss. 4, pp. 592-611, DOI: 10.1016/j.jbusvent.2006.05.003.

Lumpkin G.T., Dess G.G., 1996, Clarifying the entrepreneurial orientation construct and linking it to performance, "Academy of Management Review", vol. 21(1), pp. 135-172, DOI: $10.2307 / 258632$.

Mażewska M., 2014, Raport o firmach dziatajacych w parkach i inkubatorach technologicznych w Polsce w 2013 r., SOOiPP, Poznań/Warszawa.

Miller D., 1983, The Correlates of Entrepreneurship in Three Types of Firms, "Management Science", vol. 29(7), pp. 770-791, DOI: 10.1287/mnsc.29.7.770.

Mintzberg H., 1973, Strategy-making in three modes, "California Management Review", vol. 16(2), pp. 44-53, DOI: 10.2307/41164491.

Pichlak M., 2012, Uwarunkowania innowacyjności organizacji. Studium teoretyczne i uyniki badań empirycznych, „Difin”, Warszawa.

Pukkinen T., 2018, The role of entrepreneurial orientation and dynamic capabilities in firm performance, Turun Yliopiston Julkaisuja - Annales Universitatis Turkuensis, Sarja ser. E, osa - t. 26, Oeconomica, Turku.

Rauch A., Wiklund J., Lumpkin G., Frese M., 2009, Entrepreneurial orientation and business performance: An assessment of past research and suggestions for the future, „Entrepreneurship: Theory \& Practice", vol. 33(3), pp.761-787, DOI: 10.1111/j.15406520.2009.00308.x.

Rudawska J., 2016, Parki technologicæne na rzecz. wspótdziałania $i$ innowacji spotecznych, „Innowacje społeczne. Jak mierzyć efekty innowacji społecznych?”, Instytut Badań Rynku, Konsumpcji i Koniunktur, Warszawa.

Rudawska J., 2017, Innowacyjność organizacji - istota i pomiar, „Europa Regionum”, t. XXXI., s. 9-21, DOI: 10.18276/er.2017.31-01.

Wales W.J., 2016, Entrepreneurial orientation: A review and synthesis of promising research directions, "International Small Business Journal", vol. 34, pp. 3-15, DOI: 10.1177 / 0266242615613840 . 
Wales W.J., Patel P.C., Parida V., Kreiser P.M., 2013, Nonlinear Effects of Entrepreneurial Orientation on Small Firm Performance: The Moderating Role of Resource Orchestration Capabilities, "Strategic Entrepreneurship Journal", vol. 7(2), pp. 93-121, DOI: $10.1002 /$ sej.1153.

Wiklund J., Shepherd D., 2003, Knowledge-based resources, entrepreneurial orientation, and the performance of small and medium-sized businesses, "Strategic Management Journal", vol. 24, pp. 1307-1314, DOI: 10.1002/smj.360.

Wójcik-Karpacz A., 2017, Orientacja przeedsiebiorcza a uynik firmy. Problem pomiaru nyniku, „Studia i Prace Kolegium Zarządzania i Finansów”, z. 153, s. 143-160.

Wójcik-Karpacz A., 2019, Zdolności organizacyjne w kontekście wyników przedsiebiorstwa. Aspekty teoretyczne i myniki badan empirycznych, PWN, Warszawa.

Wójcik-Karpacz A., Karpacz J., Pavlov D., Rudawska J., 2019, Wphyw orientacji præ̨edsiebiorczej na mynik przedsiebiorstwa, „Przegląd Organizacji”, nr 1, s. 11-19, DOI: 10.33141/po.2019.01.02.

Wójcik-Karpacz A., Rudawska J., 2016, Instytucjonalne formy wspierania przeedsiebiorczości w Polsce, „Prace Naukowe Uniwersytetu Ekonomicznego we Wrocławiu”, nr 419, s. 248-264, DOI: 10.15611/pn.2016.419.22.

Zbierowski P., 2012, Orientacja pozytywna organizacji mysokiej efektywności, Wolters Kluwer Polska, Warszawa. 